\title{
ВЛИЯНИЕ РАЗМЕРОВ СЕЛЬСКОХОЗЯЙСТВЕННЫХ ПРЕДПРИЯТИЙ НА ЭФФЕКТИВНОСТЬ ПРОИЗВОДСТВА
}

\author{
Л.Н. Иванихина (фото)
}

к.э.н., доцент, профессор кафедры экономики и менеджмента А.А. Иванихин

к.э.н., доцент, профессор кафедры экономики и менеджмента ФГБОУ ВО Ярославская ГСХА, г. Ярославль

Для эффективности функционирования сельскохозяйственных предприятий немаловажное значение имеют уровень хозяйственной концентрации и размеры хозяйств. Размеры сельскохозяйственных предприятий в стране формировались и формируются под влиянием различных факторов: политических, экономических, природных и социальных [1]. При этом не всегда экономистами учитывается и планируется эффект масштаба. На современном этапе функционирования аграрного комплекса по-прежнему остаётся актуальным вопрос изучения влияния размеров предприятий на эффективность производства. Основная цель данных исследований заключается в обосновании наиболее эффективного уровня хозяйственной концентрации и размеров производства в сельскохозяйственных предприятиях. Наши исследования также были направлены на установление взаимосвязи между размерами предприятий и эффективностью производства.

Объектом исследования явилась производственная и финансо-

The concentration of production, the size of agricultural enterprises, economic efficiency, the level of profitability of production, the scale effect вая деятельность коллективных сельскохозяйственных предприятий Ярославского муниципального района Ярославской области.

При выборе основного показателя, характеризующего размеры предприятий, мы остановились на экономическом показателе стоимости товарной продукции (табл. 1). В качестве обобщающего показателя эффективности производства рассматривали уровень рентабельности производства.

Группировка по стоимости товарной продукции позволила выявить три группы предприятий. В первую группу вошло 5 предприятий с объёмом реализации продукции свыше 300 миллионов рублей, во вторую группу - 2 предприятия с объёмом реализации продукции от 150 до 300 миллионов рублей, и самой многочисленной оказалась третья группа - 18 предприятий, с объёмом реализации продукции до 150 миллионов рублей.

Первая группа предприятий представлена агропромышленными предприятиями, в неё вошли такие предприятия, как: ООО «ТК Ярославский», ООО племзавод «Родина», ЗАО «АФ «Пахма», $A O$ «Племзавод Ярославка», ООО «Север». Тепличный комбинат 
(ООО «ТК Ярославский») и птицефабрика (ООО «Север») имеют высокий уровень автоматизации трудовых процессов, два предприятия из трёх, специализирующиеся на молочном скотоводстве, имеют собственные цеха по переработке молока и производству молочной продукции.

Во вторую группу вошли два предприятия: ОАО «Племзавод им. Дзержинского» и ООО «Меленковский». Оба предприятия специализируются на молочном скотоводстве.

Остальные предприятия вошли в третью группу. Из 18 предприятий 16 специализируется на молочном скотоводстве и 2 предприятия - на выращивании продукции растениеводства.

На долю предприятий первой группы приходится 64,4\% общей стоимости товарной продукции района, в предприятиях данной группы работает $47,3 \%$ работников, здесь сосредоточено $42,4 \%$ стоимости основных средств, 35,8\% энергетических мощностей.

Предприятия Ярославского муниципального района в основном специализируются на производстве продукции молочного скотоводства. В первой группе три предприятия из пяти имеют данную специализацию. На их долю приходится $32,8 \%$ общего поголовья коров района, они производят $42,9 \%$ общего объёма молока. Хозяйства первой группы можно отнести к крупным по размерам предприятиям для условий Ярославской области.

Размеры этих предприятий позволяют осуществлять не только научно-технический прогресс в отрасли, но и формируют современный социальный и культурный облик сельских поселений, играя ведущую роль в поддержке инженерной и социальной инфраструктуры села.

Третья группа предприятий представлена 18-ю небольшими по размерам хозяйствами со средней численностью работников 55,4 человека в расчёте на одно предприятие.

Преимущества крупного производства наглядно прослеживаются в таблице 2. Показатели, приведённые в таблице, свидетельствуют о более высоком уровне интенсивности в хозяйствах первой группы по сравнению с предприятиями второй и третьей групп. В предприятиях первой группы поголовье коров в 3,5 раза больше в расчёте на 1 предприятие, чем в третьей группе, за-

Таблица 1 - Группировка коллективных сельскохозяйственных предприятий Ярославского муниципального района по размерам производства (по данным 2017 года)

\begin{tabular}{|c|c|c|c|c|}
\hline \multirow[b]{2}{*}{ Показатель } & \multicolumn{3}{|c|}{ Выручка от реализации продукции, млн руб. } & \multirow{2}{*}{$\begin{array}{c}\text { Итого по } \\
\text { району }\end{array}$} \\
\hline & $\begin{array}{c}\text { I гр. - свыше } \\
300\end{array}$ & II гр. - 150-300 & III гр. - до 150 & \\
\hline Количество предприятий, ед. & 5 & 2 & 18 & 25 \\
\hline $\begin{array}{l}\text { Выручка от реализации продукции: } \\
\text { - всего, тыс. руб. } \\
\text { - в \% к итогу }\end{array}$ & $\begin{array}{c}2265697 \\
64,4\end{array}$ & $\begin{array}{c}356081 \\
10,1\end{array}$ & $\begin{array}{c}898035 \\
25,5\end{array}$ & $\begin{array}{c}3519813 \\
100,0\end{array}$ \\
\hline $\begin{array}{l}\text { Среднегодовая численность работников: } \\
\text { - всего, чел. } \\
\text { - в \% к итогу }\end{array}$ & $\begin{array}{l}1206 \\
47,3\end{array}$ & $\begin{array}{l}345 \\
13,5\end{array}$ & $\begin{array}{r}998 \\
39,2\end{array}$ & $\begin{array}{l}2549 \\
100,0\end{array}$ \\
\hline $\begin{array}{l}\text { Среднегодовая стоимость основных средств: } \\
\text { - всего, тыс. руб. } \\
\text { - в \% к итогу }\end{array}$ & $\begin{array}{c}4591757 \\
42,4\end{array}$ & $\begin{array}{c}690352 \\
6,4\end{array}$ & $\begin{array}{c}5533230 \\
51,2 \\
\end{array}$ & $\begin{array}{c}10815339 \\
100,0\end{array}$ \\
\hline $\begin{array}{l}\text { Поголовье коров: } \\
\text { - всего, гол. } \\
\text { - в \% к итогу }\end{array}$ & $\begin{array}{c}3445 \\
32,8 \\
\end{array}$ & $\begin{array}{c}1901 \\
18,1 \\
\end{array}$ & $\begin{array}{c}5147 \\
49,1 \\
\end{array}$ & $\begin{array}{c}10493 \\
100,0 \\
\end{array}$ \\
\hline $\begin{array}{l}\text { Произведено молока: } \\
\text { - всего, ц } \\
\text { - в \% к итогу }\end{array}$ & $\begin{array}{c}323973 \\
42,9\end{array}$ & $\begin{array}{c}129160 \\
17,1\end{array}$ & $\begin{array}{c}301590 \\
40,0\end{array}$ & $\begin{array}{c}754723 \\
100,0\end{array}$ \\
\hline $\begin{array}{l}\text { Энергетические мощности: } \\
\text { - всего, л.с. } \\
\text { - в \% к итогу }\end{array}$ & $\begin{array}{c}71788 \\
35,8\end{array}$ & $\begin{array}{c}18086 \\
9,0\end{array}$ & $\begin{array}{c}110563 \\
55,2\end{array}$ & $\begin{array}{c}200437 \\
100,0\end{array}$ \\
\hline $\begin{array}{l}\text { Расход электроэнергии: } \\
\text { - всего, тыс. кВт-ч } \\
\text { - в \% к итогу }\end{array}$ & $\begin{array}{c}39810 \\
79,3\end{array}$ & $\begin{array}{c}2006 \\
4,0\end{array}$ & $\begin{array}{c}8386 \\
16,7\end{array}$ & $\begin{array}{c}50202 \\
100,0\end{array}$ \\
\hline
\end{tabular}


Таблица 2 - Уровень интенсивности ведения сельскохозяйственного производства в хозяйствах Ярославского муниципального района в зависимости от размеров производства в 2017 году

\begin{tabular}{|c|c|c|c|c|}
\hline \multirow[t]{2}{*}{ Показатель } & \multicolumn{3}{|c|}{ Выручка от реализации продукции, млн руб. } & \multirow{2}{*}{$\begin{array}{l}\text { В среднем } \\
\text { по району }\end{array}$} \\
\hline & I гр. - свыше 300 & II гр. - 150-300 & III гр. - до 150 & \\
\hline Количество предприятий, ед. & 5 & 2 & 18 & 25 \\
\hline $\begin{array}{l}\text { Численность работников в расчёте } \\
\text { на } 1 \text { предприятие, чел. }\end{array}$ & 241,2 & 172,5 & 55,4 & 102,0 \\
\hline Отработано 1 работником в год, ч & 1786,0 & 1739,0 & 1981,0 & 1856,0 \\
\hline Оплата 1 чел.-ч, руб. & 191,6 & 140,3 & 118,9 & 154,7 \\
\hline Фондовооружённость 1 работника, тыс. руб. & 3807,4 & 2001,0 & 5544,3 & 4242,9 \\
\hline Уровень износа основных средств, \% & 25,2 & 35,6 & 26,9 & 26,7 \\
\hline Энерговооружённость 1 работника, л.с. & 59,5 & 52,4 & 110,8 & 78,6 \\
\hline $\begin{array}{l}\text { Поголовье коров в расчёте } \\
\text { на } 1 \text { предприятие, гол. }\end{array}$ & 1148,3 & 950,5 & 321,7 & 499,7 \\
\hline $\begin{array}{l}\text { Затраты материально-денежных средств в } \\
\text { расчёте на } 1 \text { корову, тыс. руб. }\end{array}$ & 186,3 & 141,8 & 143,9 & 157,5 \\
\hline $\begin{array}{l}\text { Затраты труда на } 1 \text { ц произведённого } \\
\text { молока, чел.-ч }\end{array}$ & 1,06 & 1,73 & 1,99 & 1,56 \\
\hline Уровень товарности молока, \% & 94,8 & 91,7 & 93,4 & 93,7 \\
\hline $\begin{array}{l}\text { Полная себестоимость } 1 \text { ц реализованного } \\
\text { молока, руб. }\end{array}$ & 1931,0 & 1880,0 & 2259,0 & 2053,0 \\
\hline Цена реализации 1 ц молока, руб. & 2718,0 & 2593,0 & 2449,0 & 2590,0 \\
\hline
\end{tabular}

траты материально-денежных средств в расчёте на корову на 29,5\% выше, а затраты труда на 1 ц молока на 46,7\% ниже, чем в хозяйствах третьей группы. За счёт того, что продуктивность коров в хозяйствах первой группы на 60,5\% выше аналогичного показателя в третьей группе, предприятия первой группы имеют существенно ниже себестоимость 1 ц реализованного молока. Предприятия первой группы обеспечивают более высокое качество молока, что отражается на цене реализации и уровне товарности.

Несмотря на то, что фондовооружённость и энерговооружённость в предприятиях третьей группы очень высокая, и при этом работники работают на $11 \%$ больше по времени, чем в предприятиях первой группы, производительность труда у них в 2 раза, а фондоотдача в 3 раза ниже.

Все вышеперечисленные факторы привели к тому, что предприятия первых двух групп имеют положительный финансовый результат от хозяйственной деятельности, а предприятия третьей группы - отрицательный (табл. 3).

Средства государственной поддержки существенно больше (в 31,5 раза) в предприятиях первой группы, чем в третьей, и используются они наиболее эффективно именно в крупных хозяйствах.
Крупные предприятия имеют большую инвестиционную привлекательность. Исходя из размера полученной чистой прибыли (около 53 млн руб. в расчёте на 1 предприятие), в таких хозяйствах имеется финансовая возможность приобретать и эффективно использовать современные дорогостоящие машины и оборудование. Как показали наши исследования, только в крупных хозяйствах возможно создание условий для высокоэффективного производства, переработки продукции в своих целях, развития других сфер деятельности. Уровень рентабельности производства в предприятиях первой группы оказался на 31,3 п.п. выше, чем в предприятиях третьей группы.

Группировки хозяйств по их размерам и эффективности производства, проводимые многочисленными исследователями, показывают сравнительно большую эффективность крупных хозяйств по численности работников, площади земли и объёму производимой продукции [2]. Наши исследования также свидетельствуют об этом.

\section{Вывод}

Концентрация производства оказывает положительное влияние на эффективность про- 
Таблица 3 - Эффективность сельскохозяйственного производства в хозяйствах Ярославского муниципального района в зависимости от размеров производства в 2017 году

\begin{tabular}{|c|c|c|c|c|}
\hline \multirow{2}{*}{ Показатель } & \multicolumn{3}{|c|}{ Выручка от реализации продукции, млн руб. } & \multirow{2}{*}{ По району } \\
\hline & І гр. - свыше 300 & II гр. $-150-300$ & III гр. - до 150 & \\
\hline Количество предприятий, ед. & 5 & 2 & 18 & 25 \\
\hline $\begin{array}{l}\text { Произведено товарной продукции: } \\
\text { - на } 1 \text { работника, тыс. руб. } \\
\text { - на } 1 \text { чел-ч затрат труда, руб. }\end{array}$ & $\begin{array}{l}1878,7 \\
1051,9\end{array}$ & $\begin{array}{c}1032,1 \\
593,5\end{array}$ & $\begin{array}{l}899,8 \\
454,2\end{array}$ & $\begin{array}{c}1380,9 \\
743,9\end{array}$ \\
\hline $\begin{array}{l}\text { Получено валовой прибыли (убытка) в рас- } \\
\text { чёте на } 1 \text { предприятие, тыс. руб. }\end{array}$ & 94814,6 & 13650,5 & $-2525,2$ & 18236,8 \\
\hline $\begin{array}{l}\text { Получено государственной поддержки из } \\
\text { бюджетов всех уровней: } \\
\text { - всего, тыс. руб. } \\
\text { - в расчёте на } 1 \text { предприятие, тыс. руб. }\end{array}$ & $\begin{array}{c}263718,0 \\
52743,6\end{array}$ & $\begin{array}{c}18408,0 \\
9204,0\end{array}$ & $\begin{array}{c}30166,0 \\
1675,9\end{array}$ & $\begin{array}{c}312292,0 \\
12491,7\end{array}$ \\
\hline $\begin{array}{l}\text { Получено чистой прибыли (убытка): } \\
\text { - всего, тыс. руб. } \\
\text { - в расчёте на } 1 \text { предприятие, тыс. руб. }\end{array}$ & $\begin{array}{c}286196,0 \\
57239,2\end{array}$ & $\begin{array}{l}62921,0 \\
31460,5\end{array}$ & $\begin{array}{c}-163391,0 \\
-9077,3\end{array}$ & $\begin{array}{c}185726,0 \\
7429,0\end{array}$ \\
\hline Продуктивность коров, ц & 94,04 & 67,94 & 58,59 & 71,93 \\
\hline Фондоотдача на 1 руб., руб. & 0,49 & 0,52 & 0,16 & 0,33 \\
\hline Уровень рентабельности производства, \% & 26,5 & 8,3 & $-4,8$ & 14,9 \\
\hline
\end{tabular}

изводства. При специализации предприятий на молочном скотоводстве наиболее экономически эффективными в условиях Ярославского муниципального района оказались предприятия с пого- ловьем коров свыше 1000 голов, численностью работников около 250 человек [3] и объёмом реализации продукции свыше 300 миллионов рублей.

\section{Лumepamypa}

1. Крячков, И.Т. Оптимизация размеров сельскохозяйственных предприятий как условие расширенного воспроизводства в АПК [Текст] / И.Т. Крячков, А.В. Михилев, Л.И. Крячкова, О.Н. Пронская // Вестник Курской государственной сельскохозяйственной академии. - 2013. - № 2. - С. 9-10.

2. Забутов, С.Ю. Влияние размеров сельскохозяйственных предприятий на эффективность производства [Текст] / С.Ю. Забутов // Аграрный вестник Урала. - 2010. - № 1 (67). - С. 29 -32.

3. Иванихин, А.А. Анализ размеров сельскохозяйственных организаций по численности работников [Текст] / А.А. Иванихин, Л.Н. Иванихина // Вестник АПК Верхневолжья. - 2019. - № 1 (45). - С. 68-71.

\section{References}

1. Kryachkov, I.T. Optimizacija razmerov sel'skohozjajstvennyh predprijatij kak uslovie rasshirennogo vosproizvodstva v APK [Tekst] / I.T. Kryachkov, A.V. Mikhilev, L.I. Kryachkova, O.N. Pronskaya // Vestnik Kurskoj gosudarstvennoj sel'skohozjajstvennoj akademii. - 2013. - № 2. - S. 9-10.

2. Zabutov, S.Yu. Vlijanie razmerov sel'skohozjajstvennyh predprijatij na jeffektivnost' proizvodstva [Tekst] / S.Yu. Zabutov // Agrarnyj vestnik Urala. - 2010. - № 1 (67). - S. 29-32.

3. Ivanikhin, A.A. Analiz razmerov sel'skohozjajstvennyh organizacij po chislennosti rabotnikov [Tekst] / A.A. Ivanikhin, L.N. Ivanikhina // Vestnik APK Verhnevolzh'ja. - 2019. - № 1 (45). - S. 68-71. 